BIORHEOLOGY, 28; 351, 1991

$0006-355 X / 91 \$ 3.00+.00$ Printed in the USA.

Copyright (c) 1991 Pergamon Press plc. All rights reserved.

\title{
Recommended Abbreviations and Units in Hematology
}

\begin{abstract}
In order to have a standardized format for reporting blood count results the International Committee for Standardization in Haematology has made the following recommendations, which have also been endorsed by the International Society of Haematology.
\end{abstract}

Constituent

Haemoglobin

Haemat ocrit

Packed cell volume

(Refers specifically to centrifugation method)

Red blood cells

(Erythrocytes)

Mean (red) cell vol ume

Mean (red) cell haemoglobin

Mean (red) cell haemoglobin concentration

White blood cells

(Leucocytes)

Platelets (Thrombocytes)

Mean platelet volume

Plat eletcrit (Thrombocrit)

Reticulocytes
Recommended

Unit

Abbreviations to

be used in report

$\mathrm{Hb}$

g/L

Hct

$(\mathrm{L} / \mathrm{L})$

PCV

$(\mathrm{L} / \mathrm{L})$

RBC

$\times 10^{12} / \mathrm{L}$

$\mathrm{MCV}$

fl

$\mathrm{MCH}$

pg

$\mathrm{MCHC}$

WBC

$\mathrm{g} / \mathrm{L}$

P1t

$\times 10^{9} / \mathrm{L}$

$\times 10 \% / \mathrm{L}$

MPV

f 1

Pct

(L/L)

Retic 